\title{
Grazing behavior of non-supplemented and supplemented heifers on Italian ryegrass pasture
}

\section{Comportamento de pastejo de bezerras recebendo ou não suplemento em pastagem de azevém}

\author{
Viviane da Silva Hampel ${ }^{*}$; Marta Gomes da Rocha²; Luciana Pötter²; \\ Sheila Cristina Bosco Stivanin ${ }^{1}$; Marcos Bernardino Alves ${ }^{1}$; \\ Lucas Munareto Cadó ${ }^{3}$; Luiz Gonzaga do Amaral Neto ${ }^{3}$; Juliano Melleu Vicente ${ }^{3}$
}

\begin{abstract}
We evaluated the grazing behavior of heifers, at two phenological stages (vegetative and reproductive) of ryegrass (Lolium multiflorum Lam.), in four times of the day (early morning, morning, evening, and evening), with heifers either exclusively grazing or with oat, or corn grain, supplementation. The experimental design was completely randomized, in sub-subdivided plot arrangement, in which the main plots were the feeding systems, the sub-plots were the phenological stages and the sub-sub-plots were the times of day. We assessed ingestion behavior along 24 hours through visual observation, on four evaluation dates, two during the vegetative stage and two during the reproductive stage, studying time spent on grazing, rumination, or other activities, as well as number and duration of, and interval between meals. Supplemented heifers remained less time at a feeding station, performed fewer bites daily and, during the reproductive stage of the ryegrass, spent more time in other activities. Grazing time of supplemented heifers was shorter in the morning and at evening, and the duration of their meals was shorter at evening. A change occurred in the pattern of time use when heifers received supplement, and when the structural and qualitative characteristics of the pasture changed during the vegetative and reproductive phenological stages of ryegrass.
\end{abstract}

Key words: Angus heifers. Feeding stations. Vegetative stage. Reproductive stage.

\section{Resumo}

O experimento foi desenvolvido com o objetivo de avaliar o comportamento de pastejo de bezerras, durante dois estádios (vegetativo e reprodutivo) fenológicos do azevém (Lolium multiflorum Lam.), em quatro turnos diários (madrugada, manhã, tarde, noite). As bezerras estavam exclusivamente em pastejo ou em pastejo e recebendo suplemento (grão de aveia ou de milho). O delineamento experimental foi inteiramente casualizado, seguindo a estrutura de parcelas sub-subdivididas sendo os sistemas alimentares as parcelas principais, os estádios fenológicos as sub-parcelas e os turnos diários as sub-subparcelas. $\mathrm{O}$ registro do comportamento ingestivo foi realizado durante 24 horas, por observação visual, em quatro datas de avaliação: duas no estádio vegetativo e duas no estádio reprodutivo do azevém. Avaliaram-se os tempos de pastejo, de ruminação e de outras atividades, além do número, tempo de duração e o intervalo entre refeições das bezerras suplementadas ou não em pastagem de azevém. As bezerras que receberam

\footnotetext{
${ }^{1}$ Discentes do Programa de Pós-Graduação em Zootecnia, Universidade Federal de Santa Maria, UFSM, Santa Maria, RS, Brasil. E-mail: vivihampel@hotmail.com; sheila_bbosco@hotmail.com; marcosalatiel@hotmail.com

${ }^{2}$ Profs., Programa de Pós-Graduação em Zootecnia, UFSM, Santa Maria, RS, Brasil. E-mail: mgdarocha@gmail.com; potter. luciana@gmail.com

${ }^{3}$ Discentes de Graduação em Zootecnia, UFSM, Santa Maria, RS, Brasil. E-mail: lucascado@hotmail.com; luiz1989@hotmail. com; julianopetzootecnia@gmail.com

* Author for correspondence
} 
suplemento permaneceram menor tempo na estação alimentar e realizaram menor número de bocados diários. No estádio reprodutivo do azevém, as bezerras suplementadas permaneceram por mais tempo em outras atividades. $\mathrm{O}$ tempo de pastejo das bezerras que receberam suplemento foi menor nos turnos da manhã e noite. A duração das refeições foi menor no período noturno para as bezerras suplementadas. O padrão do uso do tempo das bezerras foi alterado pelo recebimento de suplemento e pela mudança das características estruturais e qualitativas do azevém durante os estádios de desenvolvimento vegetativo e reprodutivo.

Palavras-chave: Angus. Estações alimentares. Estádio vegetativo. Estádio reprodutivo.

\section{Introduction}

Forage intake is a complex behavioral process undertaken by ruminants to satisfy their nutritional requirements. Production response of the animal vis-à-vis environment and management depends on appropriately scaling variables related to their daily grazing patterns, defining when to start grazing, with what intensity, with what frequency, and with what distribution of grazing events over the course of a day (GREGORINI et al., 2006).

Ruminants may have between three and five grazing events during the day, mainly in the early morning, late in the afternoon and early evening. Afternoon grazing is longer and more significant in forage intake (GREGORINI, 2012). Metz (1975) defined a meal as a group of periods in which forage is taken. According to Barbosa et al. (2007), changes in the duration of a meal result from behavioral adjustments caused by changes in canopy structure. Meals are modified by the phenological stage and by the height of ryegrass canopy (BAGGIO et al., 2008). An accumulation of stems and senescent material occurs in the forage mass as the phenological stage of the grass progresses, with a consequent reduction in the quality of the diet of the animals (PONTES et al., 2003). Also, animals seek feed stations during the grazing process, preferring some feed stations to others. The search for feed stations, the number of feed stations visited per unit of time, depends on their displacement speed and on the animal's selectivity (UNGAR; NOY-MEIR, 1988).

Studies on plant-animal relationships show that herbivore performance depends directly on the intake of dry matter, which, in turn, depends on the manner of consumption (variations in the grazing process), on the production of forage and on the inclusion, or not, of diet supplementation. Supplemented grazing animals have their ingestion behavior altered. Supplemented heifers grazing on ryegrass reduce their grazing time and spend more time in other activities (BREMM et al., 2008). The decrease in grazing time is proportional to the amount of supplement provided, without any changes in rumination time (MACARI et al., 2007), or forage intake when compared to nonsupplemented animals (BREMM et al., 2005). Although supplemented heifers change their forage selectivity by increasing the proportion of leafs to culms in the forage as grazed (FRIZZO et al., 2003), the type of supplement does not affect the variables displacement and forage intake (PIZZUTI et al., 2012).

It is unknown why and how supplemented ruminants regulate forage intake on pasture throughout the day (GREGORINI, 2012). In this study, we hypothesized that the phenological stage (vegetative or reproductive) of the grass, and the offer of energetic supplement to heifers fed on ryegrass (Lolium multiflorum Lam.) pasture may cause different behavioral patterns, and, in particular, modifications in grazing strategy, such as changing ingestion pattern within times of the day (early morning, morning, afternoon, evening).

\section{Materials and Methods}

The experiment was performed between July and November 2012 at the Universidade Federal de Santa Maria (UFSM), Santa Maria, RS, Brazil. 
Climate, according to Köppen's classification (MORENO, 1961), is humid subtropical. The soil is Paleudalf and, in the experimental area, had the following average ratios: $\mathrm{pH}-\mathrm{H}_{2} \mathrm{O}=5.0 ; \mathrm{pH}-\mathrm{SMP}=$ 5.8; \%clay $=19.2 ; \mathrm{P}=13.4 \mathrm{mg} \mathrm{L}^{-1} ; \mathrm{K}=92 \mathrm{mg} \mathrm{L}^{-1}$; $\% \mathrm{OM}=2.7 \mathrm{~m} \mathrm{~V}^{-1} ; \mathrm{Al}^{3+}=0.2$ cmolc $\mathrm{L}^{-1} ; \mathrm{Ca}^{2+}=4.6$ cmolc $\mathrm{L}^{-1} ; \mathrm{Mg}^{2+}=2.2$ cmolc $\mathrm{L}^{-1}$; saturation of bases $=56.6 \%$; saturation of $\mathrm{Al}=3 \%$. The experimental area, divided in nine paddocks, comprised 7.2 hectares, where a ryegrass pasture was established on May 1, 2012. The fertilizer consisted of $200 \mathrm{~kg}$ $\mathrm{ha}^{-1}$ of the formula $05-20-20$ (N-P-K) and $56.5 \mathrm{~kg}$ of $\mathrm{N} \mathrm{ha}^{-1}$ in urea form subdivided into two applications. The meteorological data for the months that comprised the experimental period were obtained from the UFSM Meteorological Station.

Ingestion behavior patterns were measured in heifers kept on ryegrass pastures with three treatments: exclusive pasture; pasture + ground corn supplement, and pasture + white oat grain supplement. Supplement, given daily at $2 \mathrm{pm}$, from Monday to Saturday, at $0.93 \%$ of body weight (BW), consisted of $91.4 \%$ dry matter (DM); $12.4 \%$ mineral matter (MM); $94.4 \%$ organic matter $(\mathrm{OM})$; $21.7 \%$ neutral detergent fiber (NDF) and 9.8\% crude protein (CP), for corn grains, and 91.4\% DM; 9.6\% MM; 90.3\% OM; 31.1\% NDF; $13.7 \% \mathrm{CP}$, for white oat grains.

We adopted a continuous grazing method with a variable number of animals, using Angus heifers with an initial age of eight months and 168.6 \pm 4.9 $\mathrm{kg}$. Each paddock contained three test animals and a varied number of put-and-take animals, in order to maintain forage mass between 1,500 and 2,000 $\mathrm{kg} \mathrm{ha}^{-1} \mathrm{DM}$.

Forage mass (FM, kg.ha-1) was evaluated by direct visual estimation, with double sampling. Forage from cuts was homogenized and separated into its botanic (ryegrass and other species) and structural (leaf blades, stem, dead matter and inflorescence) components. After weighing, the samples were dried at $65^{\circ} \mathrm{C}$ for $72 \mathrm{~h}$, and, afterwards, their leaf blade-to-stem ratio was measured. Canopy height $(\mathrm{cm})$ was measured from 20 different points per paddock, which were the same points used for FM evaluations.

Forage accumulation rate (FAR, $\mathrm{kg}$ ha day $\left.{ }^{-1} \mathrm{DM}\right)$ was estimated with three grazing exclusion cages per experimental unit. Stocking rate $\left(\mathrm{kg} \mathrm{ha}^{-1} \mathrm{BW}\right)$ was calculated as the sum of the average weights of the test heifers and of each put-and-take animal multiplied by the number of days it remained in each paddock and divided by the total number of days in the period. Forage allowance (FA), in $\mathrm{kg}$ DM 100 $\mathrm{kg}^{-1} \mathrm{BW}$, was calculated with the formula: (FM/28 + FAR)/stocking rate. Leaf blades allowance was obtained by multiplying FA by the average percentage of green leaf blades in FM.

Ingestion behavior pattern was simultaneously evaluated on three test heifers per paddock. Two evaluations were performed at each phenological stage of the ryegrass: on August 162012 and September 132012 for the vegetative stage, and on October 182012 and November 82012 for the reproductive stage. Data for each stage is the average of the two evaluations made in that stage.

A feed stations was defined as the half-cylinder shaped area directly in front of and on each side of the animal when its front feet are stationary and a footstep was defined as eachmovement of the forelegs (RUYLE; DWYER, 1985). The displacement patterns were assessed during the daylight grazing periods, with six cycles of ten feed stations. The number of feed stations visited per minute, time spent at each feed station, the number of steps between feed stations and the number of steps per minute (displacement pattern) were calculated from the data collected.

Grazing and rumination periods, and the time spent in other activities, were measured, during a period of 24 hours, through visual observation, by reports of activities with most occurrences at the end of a ten-minute interval (JAMIESON; HODGSON, 1979), and are reported as total time per day (minute 
day $\left.^{-1}\right)$. Time spent selecting and apprehending forage, including the displacement intervals used for diet selection, were considered as grazing periods. Rumination time was characterized by chewing activity, without seeking or apprehending forage. Time for other activities was the period in which the animal was at rest (FORBES, 1988).

Throught observation of grazing activity, we recorded the time taken to perform 20 bites, with a chronometer, during the morning and afternoon, in order to calculate the bite rate (bite minute ${ }^{-1}$ ) (HODGSON, 1982). The number of daily bites (bites day ${ }^{-1}$ ) was obtained by multiplying bite rate by daily grazing time (minutes day ${ }^{-1}$ ).

We also calculated the number and duration of meals and the interval between meals from data collected in the evaluations of ingestion behavior. A meal is a long grazing sequence with at least two successive 10-min grazing periods. A 20-min interruption of grazing by any other activity meant the end of meal and the start of the interval between meals (BAGGIO et al., 2008). The variables grazing time, rumination time, time spent in other activities, number of meals, duration and intervals of meals were measured during each of four evaluation periods, early morning (1:00 am - 06:59 am), morning (07:00 am-12:59 pm), afternoon (1:00 pm $-6: 59 \mathrm{pm})$ and evening (7:00 - 12:59 am).

Forage samples to determine the chemical characteristics were harvested by grazing simulation at dates close to the period of observations of grazing behavior. $\mathrm{DM}, \mathrm{OM}$ and $\mathrm{MM}$ ratios in the forage were measured (AOAC, 1995), whilst CP ratios were calculated according to Robertson and Van Soest (1981), and NDF ratios were calculated following (KOMAREK, 1993).

All variables had a normal distribution and no difference $(\mathrm{P}>0.05)$ was detected by variance analysis between heifers supplemented with corn or oat grain. Therefore, we combined corn and oat treatments in one experimental group, "Supplement". In the case of variables measured for a whole day, rather than within times of day (grazing, displacement patterns, bite rate and number of bites per day), the feed systems were the main plots and the phenological stages of ryegrass were the subplots. A mixed model was employed, including the fixed effect of the feed systems and phenological stages and their interactions, and the randomized effects of residue and replications within the feed systems. In the case of pasture variables, paddocks were the replications, whereas heifers were the replications in the variables of displacement pattern, bite rate and number of bites per day.

The variables related to ingestion behavior (grazing time, rumination time, time spent in other activities, number of meals, duration and intervals between meals) were evaluated in a completely randomized design, following a sub-subdivided plot structure. Feeding systems were the main plots, the ryegrass phenological stages were the sub-plots and times of day were the sub-sub-plots and each heifer in a group was a replication. A mixed model was employed, with the fixed effect being feed systems, phenological stages, times of day and their interactions and the randomized effects including residue and heifers within the feeding systems. Analysis was performed with the MIXED procedure of SAS 8.2 (SAS Institute Inc., Cary, NC, USA). Structure selection test was performed with Bayesian Information Criterion (BIC) to determine the model which would best represent data. When difference between times of day was detected, means were compared using the lsmeans option. Interactions involving feed systems, phenological stages and times of day were significant at $5 \%$. Variables also underwent Pearson's linear correlation analysis.

\section{Results and Discussion}

Meteorological data showed that, during the experimental period, the minimum temperature $\left(14^{\circ} \mathrm{C}\right)$ was close to the average low $\left(13^{\circ} \mathrm{C}\right)$, whereas maximum temperature was $7.4 \%$ higher than the average high $\left(22^{\circ} \mathrm{C}\right)$. The rainfall in August and 
November was $47 \%$ lower than average rainfall for the same period $(127 \mathrm{~mm})$, whereas rainfall during September and October (180 mm) was 43\% higher than average rainfall for the same period $(126 \mathrm{~mm})$.

We observed no interaction $(\mathrm{P}>0.05$; Table 1$)$ between feeding system and phenological stage for variables related to the structural characteristics of the pasture or to the nutritive value of the forage. Similar ratios $(\mathrm{P}>0.05)$ were recorded for the two feeding systems, exclusive or supplemented grazing. Averages between the two conditions were $1,914 \mathrm{~kg}$ $\mathrm{ha}^{-1} \mathrm{DM}$ for forage mass, $11.7 \mathrm{~cm}$ for canopy height, $39.2 \mathrm{~kg} \mathrm{ha}^{-1} \mathrm{DM}$ for forage accumulation rate, $9.9 \mathrm{~kg}$ DM $100 \mathrm{~kg}^{-1}$ BW for forage allowance, $2.6 \% \mathrm{BW}$ for leaf blade allowance and 1.0 for leaf blade: stem ratio (Table 1). Calculated CP (average 24.1\%) and NDF $(54.8 \% \mathrm{DM})$ in forage as grazed were also similar $(\mathrm{P}>0.05)$ for the two feed systems (Table 1$)$.

Table 1. Structural and quantitative characteristics of forage canopy in ryegrass "vegetative" (V) and "reproductive" (R) phenological stages grazed by non-supplemented and supplemented heifers.

\begin{tabular}{lcccccccc}
\hline \multirow{2}{*}{ Factors } & \multicolumn{9}{c}{ Variables } \\
\cline { 2 - 9 } & FM & Height & FAR & FS & L:S & LBS & CP & NDF \\
\hline Ryegrass & 1840.5 & 11.2 & 42.8 & 9.9 & 0.9 & 2.6 & 25.1 & 54.0 \\
Supplement & 1986.9 & 12.1 & 35.6 & 9.8 & 1.1 & 2.6 & 23.1 & 55.5 \\
Vegetative & 1948.8 & 11.2 & 47.7 & 9.5 & 1.6 & 4.1 & 30.9 & 48.0 \\
Reproductive & 1878.6 & 12.2 & 30.7 & 10.3 & 0.3 & 1.2 & 17.3 & 61.5 \\
SD & 6.6 & 4.9 & 9.3 & 8.1 & 7.0 & 12.1 & 3.4 & 1.3 \\
$(\mathrm{P}=)$ & & & & & & & & \\
System & 0.461 & 0.304 & 0.222 & 0.891 & 0.266 & 0.990 & 0.155 & 0.192 \\
Stage & 0.335 & 0.009 & 0.002 & 0.007 & 0.001 & 0.001 & 0.001 & 0.001 \\
Sis*Est & 0.924 & 0.116 & 0.229 & 0.149 & 0.097 & 0.425 & 0.517 & 0.381 \\
\hline
\end{tabular}

Ryegrass - heifers exclusively grazing on ryegrass pasture; Supplement - heifer grazing on ryegrass pasture with $93 \%$ BW of supplement (corn and oat grains); SD- average standard deviation; $(\mathrm{P}=)$ - significance of effect; Sis*Est- interaction between feeding systems and phenological stages; FM- forage mass $\left(\mathrm{kg} \mathrm{ha}^{-1} \mathrm{DM}\right)$; Height- height of canopy $(\mathrm{cm})$; FAR- forage accumulation rate $(\mathrm{kg}$ $\left.\mathrm{ha}^{-1} \mathrm{DM}\right)$; FS- forage supply ( $\mathrm{kg}$ DM $\left.100 \mathrm{~kg}^{-1} \mathrm{BW}\right)$; L:S- leaf blade:stem ratio; LBS- leaf blade supply (\% BW); CP- crude protein $(\%)$; NDF- neutral detergent fiber $(\%)$

Forage mass (FM, Table 1) was similar for both phenological stages of ryegrass $(\mathrm{P}>0.05)$. However, the same forage mass may provide different ratios of forage intake (DEMMENT; LACA, 1993), with changes in the animals' behavior pattern.

Ryegrass canopy height and total forage allowance were higher in the reproductive stage than in the vegetative stage $(7.4 \%$ and $7.7 \%$ higher, respectively). Conversely, forage accumulation rate, leaf blades allowance and leaf blade:stem ratio values were lower in the reproductive stage than in the vegetative stage (Table 1). Forage as grazed yielded a $78.6 \%$ higher $\mathrm{CP}$ rate and a $21.9 \%$ lower NDF rate during the vegetative stage than during the reproductive stage (Table 1). Variation in the quality and quantity of forage available over time causes the development, by herbivores, of compensatory grazing strategies through the pasture cycle (CAMARGO et al., 2012).

There was no interaction ( $\mathrm{P}>0.05$; Table 2) between feeding system and the phenological stage of the grass for variables related to displacement and feeding stations (steps between stations, steps per minute, bites per feeding station, station per minute and time at feeding station), but exclusively pasture-fed heifers spent $16.21 \%$ more time in the same feeding station (Table 2). Supplemented heifers remained less time at the feeding station. One possible reason is that, enjoying better nutritional conditions, they depended less on canopy characteristics; additionally, supplemented animals seem to be more efficient in harvesting nutrients 
from grazing (KRYSL; HESS, 1993). On the other hand, supplementation may increase the production of volatile fatty acids, especially propionic acid, which increase the animal's satiety (ROCHE et al., 2008). Heifers also spent $6.8 \%$ more time per feeding station during the vegetative stage (Table 2 ), when leaf blades allowance was $70.7 \%$ higher (Table 1). There is a positive correlation between the amount of leaf blades and time spent at the feeding station (BAGGIO et al., 2009). A high leaf blades allowance provides greater selectivity due to greater bites, coupled to an increase in time spent at the feeding station (GONÇALVES et al., 2009). More time spent at feeding stations during the vegetative stage resulted in less visits to feeding stations per minute. When forage was abundant, intake rates were high and animals had greater bite mass while traveling greater distances with more time spent seeking sites with their preferred forage (ROGUET et al., 1998). On average, heifers visited one feeding station more during the reproductive stage than during the vegetative stage (Table 2), perhaps due to lower availability of leaf blades and to an increase in inflorescences (BAGGIO et al., 2009). Time spent at a feeding station also depends on the animal's perception of other sites with better intake opportunities (PRACHE; PEYRAUD, 2001) and on the frequency of sites with under or over utilization of forage (QUADROS et al., 2003).

Table 2. Characteristics of ingestion behavior of heifers fed exclusively on pasture ('ryegrass') or supplemented ('Supplement').

\begin{tabular}{llllllllllll}
\hline \multirow{2}{*}{ Factors } & \multicolumn{10}{c}{ Variables } \\
\cline { 2 - 12 }$y$ & Sta/mi & Ste.sta & Ste/min & T/sta & Bc.est & $\mathrm{N}^{\circ}$ meal & Dr.mea & Int.mea & Graz & Rum & Oth \\
\hline Ryegrass & 6.2 & 1.8 & 11.4 & 11.1 & 4.3 & 7.9 & 69.6 & 120.7 & 512.0 & 352.9 & 575.0 \\
Supplement & 7.3 & 1.8 & 12.8 & 9.3 & 3.9 & 7.4 & 53.7 & 134.9 & 402.6 & 339.9 & 674.6 \\
V. & 6.3 & 1.8 & 12.7 & 10.8 & 4.3 & 7.8 & 63.9 & 126.4 & 481.4 & 343.5 & 602.5 \\
R. & 7.3 & 1.8 & 12.8 & 9.6 & 4.0 & 7.5 & 59.4 & 129.2 & 433.3 & 349.3 & 647.1 \\
SD & 5.9 & 5.8 & 5.9 & 5.4 & 5.1 & 5.5 & 4.5 & 5.2 & 3.1 & 6.1 & 4.2 \\
(P=) & & & & & & & & & & & \\
System & 0.096 & 0.986 & 0.183 & 0.035 & 0.238 & 0.460 & 0.007 & 0.164 & 0.001 & 0.676 & 0.016 \\
Stage & 0.001 & 0.736 & 0.227 & 0.010 & 0.249 & 0.326 & 0.100 & 0.778 & 0.011 & 0.831 & 0.110 \\
Time of day & - & - & - & - & - & 0.001 & 0.006 & 0.001 & 0.001 & 0.001 & 0.001 \\
Sis*Est & 0.668 & 0.558 & 0.551 & 0.839 & 0.480 & 0.718 & 0.002 & 0.529 & 0.090 & 0.398 & 0.024 \\
Sis*T & - & - & - & - & - & 0.892 & 0.019 & 0.681 & 0.001 & 0.022 & 0.011 \\
Est*T & - & - & - & - & - & 0.132 & 0.005 & 0.011 & 0.001 & 0.001 & 0.003 \\
\hline
\end{tabular}

Ryegrass- heifers exclusively fed on ryegrass pasture; Sup- heifers grazing on ryegrass with $0.93 \%$ BW of energetic supplement (corn or oats); V- vegetative stage of ryegrass; R- reproductive stage of ryegrass; SD- average standard deviation; $(\mathrm{P}=)$ - significance of effect; Sis*Est- interaction between feeding systems and phenological stages; Sis*T- interaction between feeding systems and times of day; Est*T- interaction between phenological stages and times of day; Sta/mi- station per minute (stations.minute ${ }^{-1}$ ); Ste. Sta- number of steps between feeding stations; Ste/min- number of steps per minute (steps.minute ${ }^{-1}$ ); T/sta- time per feeding station (minutes); $\mathrm{N}^{\circ}$ meal- number of meals; Dr.mea- duration of meals (minutes); Int.mea- interval between meals (minutes); Graz grazing time (minutes); Rum- rumination time (minutes); Oth- time spent in other activities (minutes); means followed by different small letters on the same column differ according to the lsmeans test $(\mathrm{P}<0.05)$.

The number of steps between stations, steps per minute, number of bites and stations per minute were also similar in the two feeding systems (Table 2), probably due to their similarity in canopy height, leaf blade:stem ratio and leaf blades allowance (Table 1). Whether or not we supplemented the heifers, forage as grazed provided similar $\mathrm{CP}$ and NDF ratios (Table 1). Pizzuti et al. (2012) also reported that variables related to heifer displacement were unaffected by supplementation when the animals grazed on the same forage mass and leaf blade:stem ratio. 
The higher canopy, greater forage supply, lower leaf blade:ratio and lower supply of leaf blades in the reproductive stage (Table 1), were insufficient to modify the number of steps between the feeding stations, steps per minute, and number of bites per feeding station (Table 2). Baggio et al. (2009) reported, in ryegrass and black oat pastures, a lower number of bites per feeding station in the reproductive, compared to the vegetative stage, while Glienke et al. (2010) observed that, in supplemented heifers grazing on ryegrass pasture, the number of steps between feeding stations varied between the evaluation periods.

No interaction occurred between feeding system and ryegrass phenological stage $(\mathrm{P}<0.05)$ for bite rate and daily number of bites. Bite rate was similar for both supplemented and not supplemented heifers (26.6 bites; $\mathrm{P}=0.386$ ). Bite rate is a behavioral strategy to compensate for the decrease in forage intake (HODGSON, 1990). Bite rate was unaltered for similar forage mass between feeding systems. Bite rate was greater during the ryegrass reproductive stage $(27.6$ bites; $\mathrm{P}=0.014)$, corroborating a report by Poli et al. (2001) that bite rate increases as leaf blade : stem ratio decreases (Table 1).

Heifers fed exclusively on pasture performed 23,847 bites per day, $18 \%$ more than supplemented heifers $(\mathrm{P}=0.001)$. An increase in the number of bites per day maintains satisfactory intake levels (CARVALHO et al., 1999). Intake of concentrate may enhance an additional effect on forage selection by the animal, influencing the daily number of bites, due to an increase in forage intake and to an increase in forage quality (SILVA et al., 2014). Heifers reduced the number of bites per day by $8.2 \%$ during the reproductive stage compared to the vegetative stage $(23,251$ bites per day; $\mathrm{P}=0.005)$. The low rate of leaf blades during the reproductive stage (Table 1) may have required more time for handling and grasping of forage. This is due to the fact that a second bite cannot be undertaken when a bite is in process (CARVALHO, 1997).
There was no interaction $(\mathrm{P}>0.05$; Table 2) between feeding system and ryegrass phenological stage and between feeding system and time of day for number of daily meals and interval between meals. The number of daily meals was similar between feeding systems and between phenological stages (Table 2). Average meal number in different feeding systems and stages was $7.63 \pm 0.42$. Similar daily numbers of meals were probably due to the similar structural characteristics of the canopy in the two feeding systems ( $\mathrm{P}>0.05$; Table 1$)$. On the other hand, modifications in the structural characteristics of ryegrass from the vegetative to the reproductive stage were insufficient to alter the number of meals (Table 1). Baggio et al. (2008) reported 6.07 daily feedings per day on ryegrass grazed by heifers.

The variables grazing time and rumination time did not reveal any interaction between feeding system and phenological stage (Table 2). However, feeding system and phenological stage interacted for time spent in other activities (Table 2). During the ryegrass reproductive stage, heifers exclusively on pasture had the lowest time spent in other activities. There is a contradiction in literature existent about the results of pasture management on animals' response in change of time spent in other activities. In ryegrass plus oat the time spent in other activities by heifers proved to be similar, regardless of supplementation strategy (BREMM et al., 2008). On the other hand, Pellegrini et al. (2011) reported that time spent in other activities was reduced to 0.90 minute per day during pasture utilization.

Feeding system and phenological stage of ryegrass also interacted for meal duration (Figure 1A). During the vegetative stage, meal duration (63.9 $\mathrm{min}$ ) was the same for heifers within the two feeding systems (Figure 1A). Meal duration relates directly to the speed in which the animals consume forage (CARVALHO; MORAIS, 2005). The amount of nutrients provided by the supplement at this stage was insufficient to change meal duration, probably due to the great easiness with which forage harvest occurred. Conversely, during the reproductive 
stage, grazing-exclusive heifers spent 24.8 minutes more for each meal on ryegrass. Animals change the duration and the number of meals according to the level of forage nutrient supply (BARBOSA et al., 2010). Since heifers fed on pasture alone depended exclusively on forage nutrients, they increased feeding time to supply their nutritional requirements within the same canopy structure and composition of forage as grazed on the two feeding systems (Table 1).

Figure 1. Duration of meal, grazing time, rumination time, times spent in other activities by heifers fed exclusively on pasture ('ryegrass') end supplemented ('Supplement') at phenological stages and times of day (shifts); different small letters at the same stage and time of day differ by lsmeans test $(\mathrm{P}<0.05)$; Early - early morning; Mor- morning; Aft- afternoon; Eve- evening.
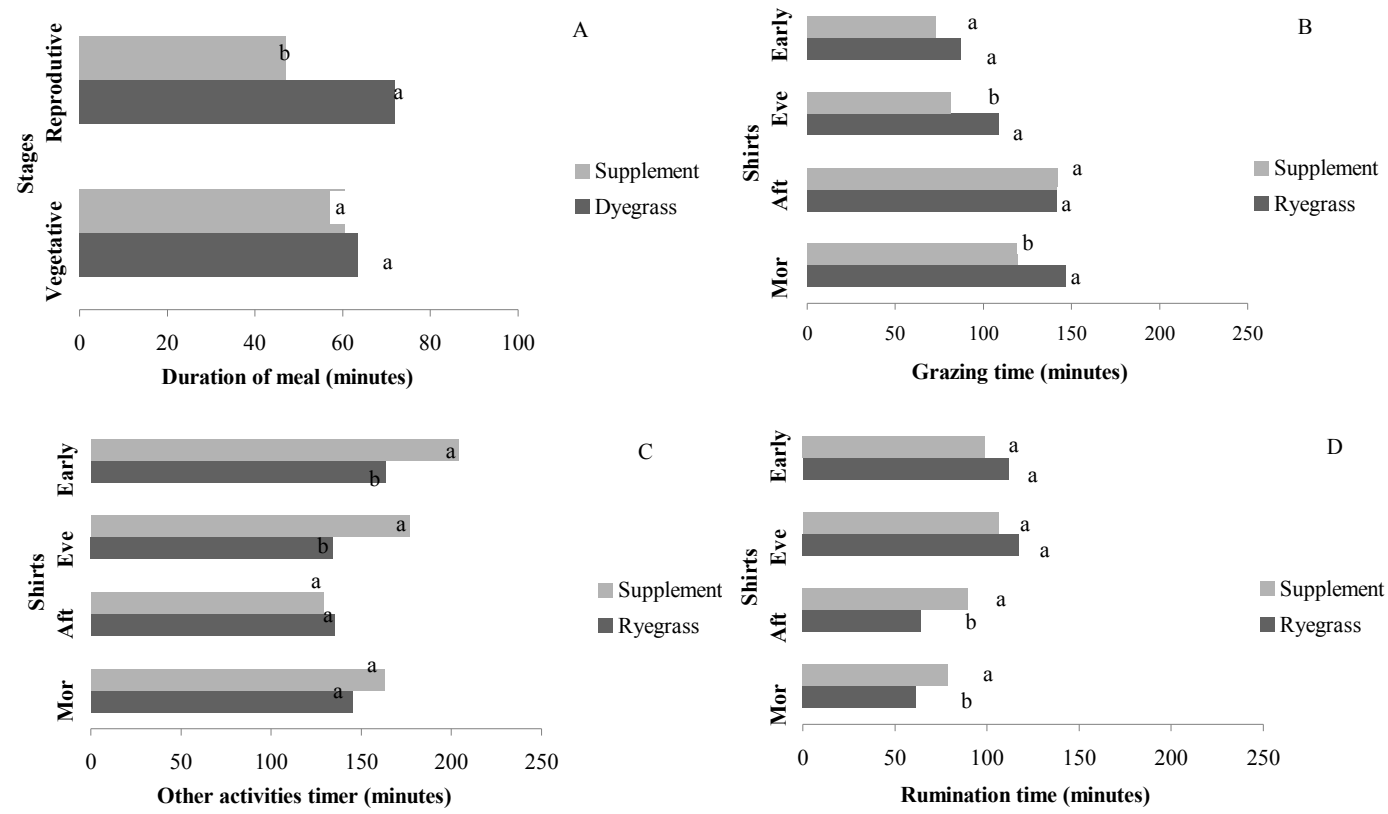

Grazing time, rumination time and time spent in other activities interacted in feeding system vs. time of day (Table 2; Figures 1B, 1D, 1C). Heifers fed only on pasture spent $23 \%$ more time grazing in the morning than supplemented heifers (Figure 1B). Grazing during this time of day corresponded to $29 \%$ of total time spent in daily grazing. Less grazing time during the morning may have been an anticipation behavior for the supplement supply at $2 \mathrm{pm}$. Grazing decisions depend on grazing environment, actual and past conditions, and on the animal's anticipatory behavior (GREGORINI, 2012). More grazing time during the morning by heifers grazing exclusively may have been a response to the hunger stimulus. According to Gregorini (2012), hunger conditions animals to start the grazing process in the morning

even though, at this time, forage has its lowest nutrient rates. Hundertmarck et al. (2012) reported that supplemented heifers had a $63.57 \%$ shorter grazing time during the two hours previous to supplementation, compared to heifers exclusively on pasture. Heifers exclusively on pasture also spent more time grazing (28 minutes) than supplemented heifers during the evening period (Figure 1B). A longer grazing time may have been a behavioral strategy for nutrient acquisition, although, as a rule, grazing time decreases during this time of day as a defense mechanism against predators (GREGORINI, 2012). Supplemented heifers may have been more efficient in forage harvest during the other times of day and, consequently, satiety reduced the evening grazing period (ROCHE et al., 2008). 
Supplemented heifers had 22\% and 29\% longer rumination times during the afternoon and the morning, respectively, when compared to heifers exclusively on pasture (Figure 1D). The sum of rumination times in the morning and the afternoon for supplemented heifers corresponded to $44.8 \%$ of the daily rumination period $(5.6 \mathrm{~h})$. The shorter rumination time spent by heifers exclusively on pasture during the morning relates to their greater grazing activity during the same time of day, since those activities are mutually exclusive. Increases or decreases in grazing time may alter other activities. Likewise, a longer rumination period by supplemented heifers during the afternoon, when supplement was offered, relate directly to a decrease in grazing time, since the type of diet affects rumination time (VAN SOEST, 1994). When there is an increase in the amount of nutrient intake, there is also an increase in chewing time (SILVA et al., 2014). Supplemented animals may have ruminated more and grazed less during the morning due to their anticipation of the $2 \mathrm{pm}$ supplementation.

Heifers exclusively on pasture spent less time in other activities during the evening and the early morning (Figure 1C). According to Di Marco and Aello (2001), animals fed exclusively on pasture require higher nutrition rates due to their greater energy demand caused by seeking and apprehension of forage, with less time for other activities during this time of day. Accordingly, time spent in other activities was greater for supplemented heifers since, according to Hodgson (1990), when grazing time decreases, there is an increase in time for other activities.

Interaction between feeding system and time of day occurred for meal duration ( $\mathrm{P}=0.019$; Figure 2A). During the evening, heifers fed exclusively on pasture realized meals 38\% longer. Supplemented heifers spent less time during meals, probably due to a combination of factors related to a better energy balance and less motivation to eat, due to satiety (BAUMONT et al., 2004). Supplementation becomes relevant for the performance of the animal when is related to the proportion of energy spent on grazing (PARDO et al., 2003).

An interaction between ryegrass phenological stage and time of day for time spent on grazing, rumination and other activities (Table 2; Figures 2B, $2 \mathrm{C}$ and $2 \mathrm{D}$ ) was observed. During the reproductive stage, grazing time in the morning and the afternoon was shorter, compared to the vegetative stage (Figure 2B). Regardless of time of day, grazing time was longer during the reproductive stage (PELLEGRINI et al., 2011; BAGGIO et al., 2008). Results obtained by activities divided by shifts of day may fine-tune this conclusion. Prache et al. (1998) reported that grazing time is longer in the reproductive stage when the green forage mass is similar for both stages. The physical factors that affect forage intake are forage fiber content, digestibility of forage and the speed with which fibers are degraded in the rumen (ROCHE et al., 2008).

We observed longer grazing period during the evening when ryegrass was in the reproductive stage (Figure 2B). Thermal comfort for Angus heifers is around $20^{\circ} \mathrm{C}$. During the reproductive stage, average temperatures during the afternoon and evening were, respectively, $30^{\circ} \mathrm{C}$ and $22^{\circ} \mathrm{C}$. Average temperature during the period within this stage $\left(23.3^{\circ} \mathrm{C}\right)$ was $4^{\circ} \mathrm{C}$ higher than average temperature during the vegetative stage. Grazing time may change due to temperature, as ruminants reduce ingestion and increase heat loss to conserve body temperature at the appropriate physiological level (VALENTE et al., 2013).

Rumination time and time spent in other activities were shorter during the afternoon in the vegetative stage (Figures 2C; 2D) due to longer time spent grazing. Responses to ingestion behavior refer to several satiety stimuli due to interactions between the ingestion and digestion behavior and to forage contents. According to Gregorini (2012), frequency in the distribution of ingestion behavior patterns may be affected by chemical fluctuations of photoassimilates, by filling and functioning of the 
rumen (GREGORINI et al., 2008), by photoperiod (GREGORINI et al., 2011) and by strategies against predators (GREGORINI, 2012). Alonger rumination period and less time spent in other activities during the vegetative stage were reported during the early morning. Nutrients are constantly released during the period in which ruminants do not graze or graze for a shorter period, such as during the evening and early morning periods (GREGORINI, 2012).

Figure 2. Grazing time, rumination time; time spent in other activities, interval between meals and duration of meal per heifer on ryegrass pasture ('ryegrass') or supplemented ('Supplement'), in times of day (shifts); different small letters within each time of day differ by lsmeans test $(\mathrm{P}<0.05)$; Early- early morning; Mor- morning; Aft- afternoon; Eve- evening.
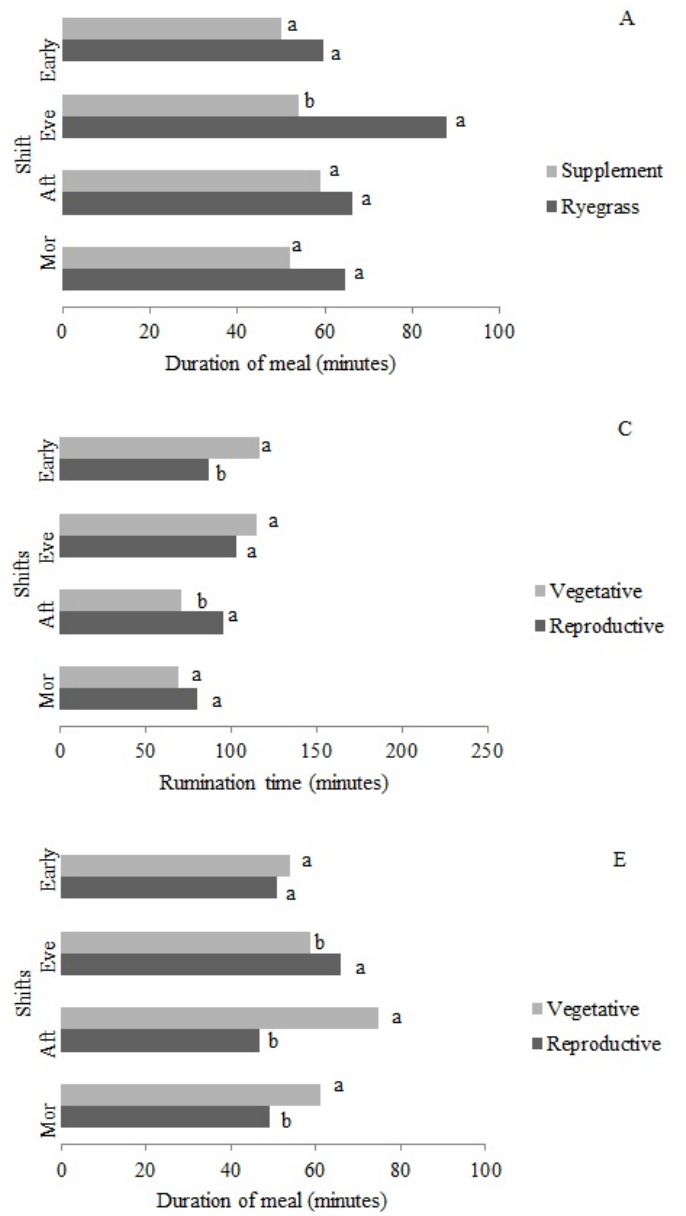

No interaction occurred ( $\mathrm{P}>0.05$; Table 2) between ryegrass phenological stage and time of day for the number of daily meals. Heifers had a greater number of meals during the afternoon and the morning ( 2.28 feedings; $\mathrm{P}=0.001$ ) and a lesser one during the evening and the early morning (1.53 feedings), in conformity with the grazing habits of ruminants presenting greater grazing events in the evening and morning (GREGORINI, 2012).

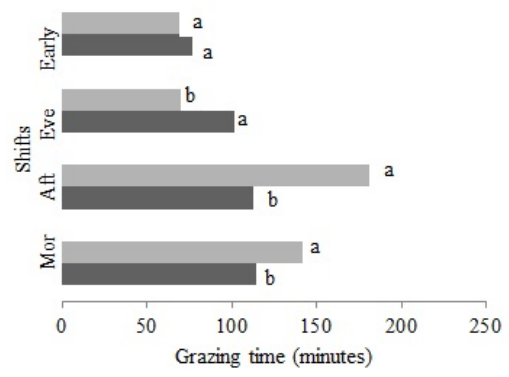

B

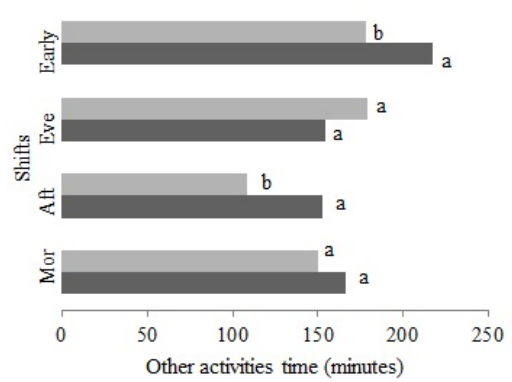

Vegetative

॥eproductive

Vegetative

- Reproductive

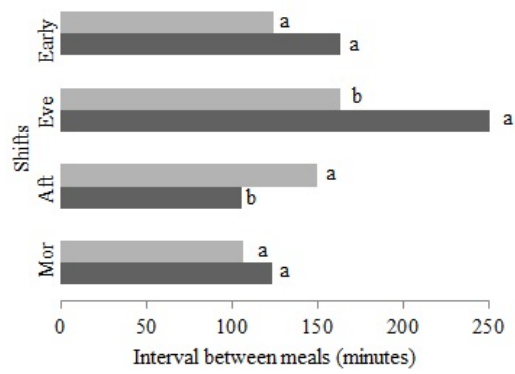

F

Vegetative

- Reproductive

Interaction between the ryegrass phenological stage and time of day occurred for meal duration (Figure 2E) and interval between meals (Figure 2F). Meals were larger during the morning and the afternoon during the vegetative stage, with less time spent during the evening meals (Figure 2E). During the afternoon, increase in the concentration of dry matter, sugars and essential fatty acids occurs due to day time fluctuations in the chemical composition 
of forage regarding the accumulation of photoassimilates and water loss by transpiration. These factors cause more efficient forage intake during the time of day since heifers are capable of maximizing the acquisition of daily energy by constant release of nutrients during the night (GREGORINI, 2012). Longer meals in the morning are due to hunger stimulus, which prompts the heifers to more intense grazing (GREGORINI, 2012).

The interval between meals during the afternoon was longer during the vegetative stage (Figure 2F). Interval between meals indicates forage quality, since meal ends when the animal reaches a certain consumption level and, at this point, the inter-meal interval starts (BARBOSA et al., 2010). According to Gregorini (2012), the ingestion-digestion behavior is molded by daily fluctuations in light intensity that stimulate the circadian release of neurotransmitters and hormones, interacting with daily fluctuations in the nutritional content of the forage. During the afternoon heifers can harvest forage with a higher rate of photo-assimilates, and thus take a greater time to start a new meal. The longest interval between meals in the evening occurred during the reproductive stage (Figure 2F). Ruminants add feed into the rumen which already contain remnants from previous feedings. The immediate metabolic consequences of the addition of a single meal may be affected by the animal's previous nutritional status (YEATES et al., 2002). Longer intervals are due to the feed type and, consequently, to the digestion products of the diet (ROCHE et al., 2008).

\section{Conclusions}

Both supplementation and the ryegrass phenological stage altered the time pattern of grazing. Supplemented heifers decrease time in the feed station and decrease the number of daily bites. These heifers reduce grazing time during the morning and the evening and duration of meals during the evening. Time spent in other activities decreases during the reproductive stage of ryegrass for heifers exclusively grazing.

\section{References}

ASSOCIATION OF OFFICIAL ANALYTICAL CHEMISTS - AOAC. Official methods of analysis. $16^{\text {th }}$ ed. Arlington: AOAC International, 1995. $1025 \mathrm{p}$.

BAGGIO, C.; CARVALHO, P. D. F.; SILVA, J. D.; ROCHA, L. D.; BREMM, C.; SANTOS, D. D.; MONTEIRO, A. Padrões de uso do tempo por novilhos em pastagem consorciada de azevém anual e aveia-preta. Revista Brasileira de Zootecnia, Viçosa, MG, v. 37, n. T11, p. 1912-1918, 2008.

BAGGIO, C.; CARVALHO, P. D. F.; SILVA, J. D. S.; ANGHINONI, I.; LOPES, M. L. T.; THUROW, J. M. Padrões de deslocamento e captura de forragem por novilhos em pastagem de azevém anual e aveia-preta manejada sob diferentes alturas em sistema de integração lavoura pecuária. Revista Brasileira de Zootecnia, Viçosa, MG, v. 38, n. 2, p. 215-222, 2009.

BARBOSA, C. M. P.; CARVALHO, P. D. F.; CAUDURO, G. F.; LUNARDI, R.; GONÇALVES, E. N.; DEVINCENZI, T. Componentes do processo de pastejo de cordeiros em azevém sob diferentes intensidades e métodos. Archivos de Zootecnia, Córdoba, v. 59, n. 225, p. 39-50, 2010.

BARBOSA, R. A.; NASCIMENTO JÚNIOR, D. D.; EUCLIDES, V. P. B.; SILVA, S. D.; ZIMMER, A. H.; TORRES JÚNIOR, R. D. A. Capim-tanzânia submetido a combinações entre intensidade e frequência de pastejo. Pesquisa Agropecuária Brasileira, Brasília, v. 42, n. 3, p. 329-340, 2007.

BAUMONT, R.; COHEN-SALMON, D.; PRACHE, S.; SAUVANT, D. A mechanistic model of intake and grazing behaviour in sheep integrating sward architecture and animal decisions. Animal Feed Science and Technology, Amsterdam, v. 112, n. 1, p. 5-28, 2004.

BREMM, C.; ROCHA, M. D.; RESTLE, J.; PILAU, A.; MONTAGNER, D. B.; FREITAS, F. D.; NEVES, F. P. Efeito de níveis de suplementação sobre o comportamento ingestivo de bezerras em pastagem de aveia (Avena strigosa Schreb.) e azevém (Lolium multiflorum Lam.). Revista Brasileira de Zootecnia, Viçosa, MG, v. 34, n. 2, p. 319-329, 2005.

BREMM, C.; SILVA, J. D.; ROCHA, M. D.; ELEJALDE, D. A. G.; OLIVEIRA NETO, R. A. D.; CONFORTIN, A. C. C. Comportamento ingestivo de ovelhas e cordeiras em pastagem de azevém-anual sob níveis crescentes de suplementação. Revista Brasileira de Zootecnia, Viçosa, MG, v. 37, n. 12, p. 2097-2106. 2008.

CAMARGO, D. G.; ROCHA, M. G.; SILVA, J. H. S.; GLIENKE, C. L.; CONFORTIN, A. C. C.; MACHADO, J. M. Características da ingestão de forragem por 
cordeiras nos estádios fenológicos da pastagem de azevém. Arquivo Brasileiro de. Medicina Veterinária e Zootecnia, Belo Horizonte, v. 64, n. 2, p. 403-410, 2012.

CARVALHO, P. C. F. A estrutura da pastagem e o comportamento ingestivo de ruminantes em pastejo. In: SIMPÓSIO SOBRE AVALIAÇÃO DE PASTAGENS COM ANIMAIS, 2., 1997, Maringá. Anais... Maringá: Universidade Estadual de Maringá, 1997. p. 25-52.

CARVALHO, P. C. F.; PRACHE, S.; DAMASCENO, J. C. O processo de pastejo: desafios da procura e apreensão da forragem pelo herbívoro. In: REUNIÃO ANUAL DA SOCIEDADE BRASILEIRA DE ZOOTECNIA, 36., 1999, Porto Alegre. Anais... Porto Alegre, 1999. p. 253268.

CARVALHO, P. C. F.; MORAES, A. Comportamento ingestivo de ruminantes: bases para o manejo sustentável do pasto. In: CECATO, U.; JOBIM, C. C. (Org.). Manejo sustentável em pastagem. Maringá: UEP, v. 1, 2005. p. $1-20$.

DEMMENT, M. W.; LACA, E. A. The grazing ruminant: models and experimental techniques to relate sward structure and intake. In: WORLD CONFERENCE ON ANIMAL PRODUCTION, 7., 1993, Edmonton. Proceedings... Edmonton: Keeling \& Mundi, 1993. p. 439-460.

DI MARCO, O. N.; AELLO, M. S. Gasto de energia da apreensão de forragem e do caminhar por bovinos em pastejo. Arquivo Brasileiro de Medicina Veterinária e Zootecnia, Belo Horizonte, v. 53, n. 1, p. 105-110, 2001.

FORBES, T. A. D. Researching the plant-animal interface: the investigation of ingestive behavior of cows and sheep. Journal of Animal Science, Champaign, v. 66, n. 9, p. 2369-2379, 1988.

FRIZZO, A.; ROCHA, M. D.; RESTLE, J.; MONTAGNER, D. B.; FREITAS, F. D.; SANTOS, D. D. Suplementação energética na recria de bezerras de corte mantidas em pastagem de inverno. Revista Brasileira de Zootecnia, Viçosa, MG, v. 32, n. 3, p. 643-652, 2003.

GLIENKE, C. L.; ROCHA, M. G. D.; CAMARGO, D. G.; PÖTTER, L.; CONFORTIN, A. C. C.; COSTA, V. G. D. Grazing ecology of female lambs on Italian ryegrass plus red clover pasture under different defoliation intensities. Revista Brasileira de Zootecnia, Viçosa, MG, v. 39, n. 1, p. 51-60, 2010.

GONÇALVES, E. N.; CARVALHO, P. D. F.; DEVINCENZI, T.; LOPES, M. L. T.; FREITAS, F. D.; JACQUES, A. V. A. Relações planta-animal em ambiente pastoril heterogêneo: padrões de deslocamento e uso de estações alimentares. Revista Brasileira de Zootecnia, Viçosa, MG, v. 38, n. 11, p. 2121-2126, 2009.
GREGORINI, P. Diurnal grazing pattern: its physiological basis and strategic management. Animal Production Science, Collingwood, v. 52, n. 7, p. 416-430, 2012.

GREGORINI, P.; GUNTER, S. A.; BECK, P.A.; SODER, K. J.; TAMMINGA, S. REVIEW: the interaction of diurnal grazing pattern, ruminal metabolism, nutrient supply and management in cattle. The Professional Animal Scientist, Champaign, v. 24, n. 4, p. 308-318, 2008.

GREGORINI, P.; GUNTER, S. A.; BOWMAN, M. T.; CALDWELL, J. D.; MASINO, C. A.; COBLENTZ, W. K.; BECK, P. A. Effect of herbage depletion on shortterm foraging dynamics and diet quality of steers grazing wheat pastures. Journal of Animal Science, Champaign, v. 98, n. 11, p. 3824-3830, 2011.

GREGORINI, P.; TAMMINGA, S.; GUNTER, S. A. Review: behavior and daily grazing patterns of cattle. The Professional Animal Scientist, Champaign, v. 22, n. 3, p. 201-209, 2006.

HODGSON, J. Grazing management: science into practice. England: Longman Scientific \& Technical, 1990. $203 \mathrm{p}$.

HODGSON, J. Influence of sward characteristics on diet selection and herbage intake by the grazing animal. In: HACKER, J.B. (Ed.). Nutritional limits to animal production from pastures: proceedings of an international symposium held at St. Lucia, Queensland, Australia, August 24-28, 1981. Farnham Royal, UK: Commonwealth Agricultural Bureaux, 1982.

HUNDERTMARCK, A. P.; PÖTTER, L.; ROSA, A. T. N.; ELOY, L. R.; HAMPEL, V. S.; STIVANIN, S. C. B. Comportamento ingestivo de bezerras de corte em pastagem de azevém recebendo diferentes níveis de suplemento energético. In: REUNIÃO ANUAL DASOCIEDADE BRASILEIRA DE ZOOTECNIA, 49., 2012, Brasília. Anais... Brasília: [s.n.], 2012. CD-ROM.

JAMIESON, W. S.; HODGSON, J. The effect of daily herbage allowance and sward characteristics upon the ingestive behavior of calves under strip-grazing management. Grass and Forage Science, Oxford, v. 34, n. 4, p. 261-271, 1979.

KOMAREK, A. R. A fiber bag procedure for improved efficiency of fiber analyses. Journal of Dairy Science, Madison, v. 76, p. 250, 1993. Supplement 1.

KRYSL, L. J.; HESS, B. W. Influence of supplementation on behavior of grazing cattle. Journal of Animal Science, Champaign, v. 71, n. 9, p. 2546-2555, 1993.

MACARI, S.; ROCHA, M. G.; PÖTTER, L.; ROMAN, J.; BREMM, C.; COSTA, V. G. Comportamento ingestivo diurno de novilhas de corte recebendo níveis 
de suplemento. Ciência Rural, Santa Maria, v. 37, n. 6, p. 1746-1752, 2007.

METZ, J. H. M. Time patterns of feeding and rumination in domestic cattle. Veenman: [s.n.], 1975. v. 5.

MORENO, J. A. Clima do Rio Grande do Sul. Porto Alegre: Secretaria da Agricultura, 1961. 41 p.

PARDO, R. M. P.; FISCHER, V.; BALBINOTTI, M.; MORENO, C. B.; FERREIRA, E. X.; VINHAS, R. I.; MONKS, P. L. Comportamento ingestivo diurno de novilhos em pastejo submetidos a níveis crescentes de suplementação energética. Revista Brasileira de Zootecnia, Viçosa, MG, v. 32, n. 6, p. 1408-1418, 2003.

PELLEGRINI, L. G.; MONTEIRO, A. L. G.; NEUMANN, M.; CARVALHO, P. C. F.; SILVA, A. L. P.; LUSTOSA, S. B. C.; PELleGrin, A. C. R. S. Comportamento de cordeiros em pastejo de azevém (Lolium multiflorum) em diferentes fases fenológicas submetidos à adubação nitrogenada. Revista Ceres, Viçosa, MG, v. 58, n. 3, p. 329-335, 2011.

PIZZUTI, L. A. D.; ALVES FILHO, D. C.; BRONDANI, I. L.; PACHECO, P. S.; FREITAS, L. D. S.; SEGABINAZZI, L. R.; MARIAN, A.; TEIXEIRA, O. D. S. Behavior pattern of beef heifers supplemented with different energy sources on oat and ryegrass pasture. Revista Brasileira de Zootecnia, Viçosa, MG, v. 41, n. 8, p. 1921-1927, 2012.

POLI, C. H. E. C.; ROCHS, M. G.; PIRES, C. C.; FARINATTI, L. H. E.; MONTAGNER, D.; BICA, G. The effect of feed supplementation swards characteristics on the ingestive behavior of grazing ewes. In International Grassland Congress, Santa Maria, v. 19, p. 7-13, 2001.

PONTES, S. L.; NABINGER, C.; CARVALHO, P. C. F.; TRINDADE, J. K.; MONTARDO, D. P.; SANTOS, R. J. Variáveis morfogênicas e estruturais de azevém anual (Lolium multiflorum Lam.) manejado em diferentes alturas. Revista Brasileira de Zootecnia, Viçosa, MG, v. 4, n. 32, p. 814-820, 2003.

PRACHE, S.; PEYRAUD, J. Foraging: behavior and intake in temperate cultivated grassland. In: INTERNATIONAL GRASSLAND CONGRESS, 19., 2001, São Pedro. Proceedings... São Pedro: FEALQ, 2001. p. 309-319.

PRACHE, S.; ROGUET, C.; PETIT, M. How degree of selectivity modifies foraging behaviour of dry ewes on reproductive compared to vegetative sward structure. Applied Animal Behaviour Science, New York, v. 57, n. 1, p. 91-108, 1998.

QUADROS, F. L F.; TREVISAN, N. de B.; SILVA, A. C. F.; BANDINELLI, D. G.; MARTINS, C. E. N.; ALVES FILHO, D. C. Preferência por sítios de pastejo em pastagem de aveia e azevém submetida a diferentes biomassas de lâmina foliar verde. In: REUNIÃO ANUAL DASOCIEDADE BRASILEIRA DE ZOOTECNIA, 40., 2003, Santa Maria. Anais... Santa Maria: Universidade Federal de Santa Maria, 2003. CD-ROM.

ROBERTSON, J. B.; VAN SOEST, P. J. The detergent system of analysis and its application to human foods. In: JAMES, W. P. T.; THEANDER, O. (Ed.). The analysis of dietary fiber in food. New York: Marcel Dekker, 1981. p. 123-158.

ROCHE, J. R.; BLACHE, D.; KAY, J. K.; MILLER, D. R.; SHEAHAN, A. J.; MILLER, D. W. Neuroendocrine and physiological regulation of intake with particular reference to domesticated ruminant animals. Nutrition Research Reviews, Cambridge, v. 21, n. 2, p. 207-234, 2008.

ROGUET, C.; DUMONT, B.; PRACHE, S. Selection and use of feeding sites and feeding stations by herbivores: a review. Annales de Zootechnie. EDP Sciences, Paris, v. 47, n. 4, p. 225-244, 1998.

RUYLE, G. B.; DWYER, D. D. Feeding stations of sheep as an indicator of diminished forage supply. Journal of Animal Science, Champaign, v. 61, n. 2, p. 349-352, 1985.

SILVA, A. L. N.; SILVA, R. R.; CARVALHO, G. G. P.; SILVA, F. F.; LINS, T. O. J. D. A.; ZEOULA, L. M.; FRANCO, S. L.; SOUZA, S. O.; PEREIRA, M. M. S.; BARROSO, D. S. Correlation between ingestive behaviour, intake and performance of grazing cattle supplemented with or without propolis extract (LLOS $\left.{ }^{\circledR}\right)$. Journal of Agricultural and Crop Research, v. 2, n. 1, p. 1-10, 2014.

UNGAR, E. D.; NOY-MEIR, I. Herbage intake in relation to availability and sward structure: grazing processes and optimal foraging. Journal of Applied Ecology, v. 25, n. 3, p. 1045-1062, 1988.

VALENTE, E. E. L.; PAULINO, M. F.; DETMANN, E.; VALADARES FILHO, S. C.; CHIZZOTTI, M. L.; SILVA, A. G.; MACIEL, I. F. S. Grazing behavior and locomotion of young bulls receiving different nutritional plans in a tropical pasture. Asian-Australasian Journal of Animal Sciences (AJAS), v. 26, n. 12, p. 1717-1725, 2013.

VAN SOEST, P. J. Nutritional ecology of the ruminant. $2^{\text {th }}$ ed. Ithaca: Cornell University Press, 1994. n. 2, 476 p.

YEATES, M. P.; TOLKAMP, B. J.; KYRIAZAKIS, I. The relationship between meal composition and longterm diet choice. Journal of animal science, Champaign, v. 80, n. 12 , p. 3165-3178, 2002. 
